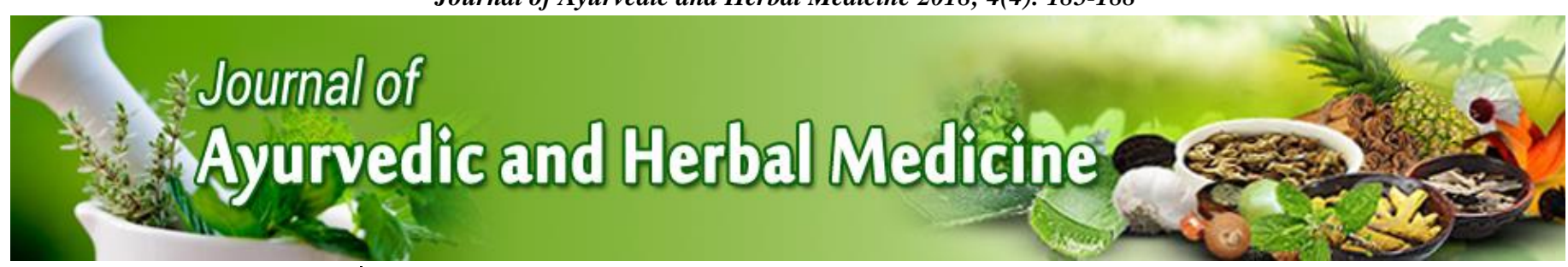

\section{$\underline{\text { Review Article }}$}

ISSN: 2454-5023

J. Ayu. Herb. Med. 2018; 4(4): 185-188 (C) 2018, All rights reserved www.ayurvedjournal.com Received: 13-11-2018 Accepted: 09-12-2018
*Corresponding author:

\section{Sarvananda}

Department of Botany, Faculty of Sciences, University Peradeniya, Peradeniya, Sri Lanka Email: sarvacool18[at]gmail.com

\title{
Ethnopharmacolological potential and medicinal uses of Hygrophila auriculata
}

\section{Sarvananda ${ }^{1,2}$, Amal D. Premarathna ${ }^{3,4}$}

1 Department of Botany, Faculty of Sciences, University of Peradeniya, Peradeniya, Sri Lanka

2 Jeewaka Herbal Remedies 146, Nuwara Eliya road Paradeka, Sri Lanka

3 Department of Veterinary Pathobiology, Faculty of Veterinary Medicine and Animal Science, University of Peradeniya, Peradeniya, Sri Lanka

4 Faculty of Fisheries \& Marine Science, Ocean University of Sri Lanka, Tangalle, Sri Lanka

\section{ABSTRACT}

Hygrophila auriculata is belonging to family Acanthaceae, Usually called as "Neermulli in Tamil" is a grow in wet places. It is an important herbal plant, broadly spread in Sri Lanka India, and is used to treat various diseases. Hygrophila auriculata (L.) Nees, Acanthaceae, is a source of traditional medicine; the aerial parts of the plant are used to treat blood disorders. It has various medicinal properties such as anticancer, hypoglycemic, aphrodisiac, antimicrobial, antioxidant, lipid peroxidation, hepatoprotective and hematopoietic activity. It consists of lupeol, stigmasterol, bulletin, fatty acids, and alkaloids. Commercially, it used as an ingredient in some of over the counter (OTC) formulations to treat the liver disorder and those prescribed by general tonic. In this review, talk over the pharmacological and medicinal properties of Hygrophila auriculata (Neermulli). Furthermore, need to do a clinical investigation to promote as commercial drugs.

Keywords: Hygrophila auriculata, Medicinal plant, Antitumor, Antioxidant, Neermulli.

\section{INTRODUCTION}

Hygrophila or Marsh Barbel (English) it is commonly used to call in Tamil as a Neermulli. An annual herbal plant grows up to $60 \mathrm{cms}$ altitude. The plant stem is tetragonal, hairy and stiffened at the nodes. The bark is dark brown, although the leaves are elliptic-lanceolate and hispid. The flowers are violet and somewhat purple-blue. The fruit looks like a four-sided figure, linear, glabrous and about contains $1 \mathrm{~cm}$ long seeds which are orbicular hairy and brown in color ${ }^{[1,2]}$. Tamil: Neermuli.

Distribution: Around the world found in Sri Lanka, Myanmar, Indonesia, Malaysia and throughout the plains of India, in moist habitats such as marshy margins of canals, also found in tropical Himalaya [3, 35].

Taxonomic position ${ }^{[36]}$

Kingdom: Plantae Subkingdom: Viridiplantae Infrakingdom: Streptophyta Superdivision: Embryophyta Division: Tracheophyta Subdivision: Spermatophyta

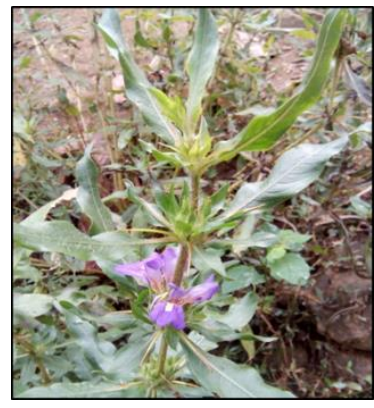

Class: Magnoliopsida Superorder Asteranae Order Lamiales Family: Acanthaceae Genus: Hygrophila R. Br. Species: auriculata

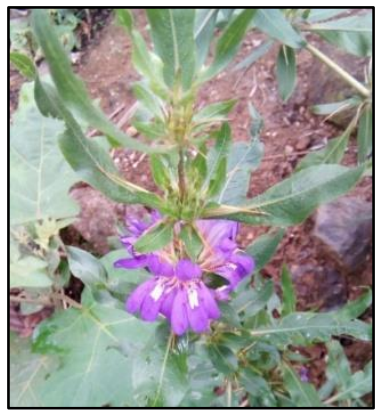

Figure(s): Hygrophila auriculato 
Leaf: The leaf is dorsiventral, smooth and even with a prominent midrib. The midrib is Plano bowed in a sectional sight with a flush adaxial side and a broad crescent abaxial side. The midrib is $750 \mu \mathrm{m}$ along the median perpendicular plane and $1 \mu \mathrm{m}$ in the parallel. In the upper surface of a leaf, the epidermis is prominent with squares cells and a prominent cuticle. Beneath the epidermis, there are about three layers of small collenchyma cells. Further below the collenchyma are four or five layers of wide thin-walled parenchyma cells. The abaxial part of the midrib has an epidermis similar to the adaxial side. These may be one or two layers of collenchyma inner to the abaxial epidermis. The remaining ground tissue consists of a wide, compact, thin-walled parenchyma cells. The vascular bundle is single and elliptical in cross-section. It is $350 \mu \mathrm{m}$ horizontally and $150 \mu \mathrm{m}$ vertically. It consists of 8-10, parallel rows of xylem elements, which are angular, thin-walled and narrow. Phloem occurs as a thin sheath along the abaxial side of the xylem. In an upper surface of a leaf, there are two small, less prominent, circular accessory strands. They are circular with a cluster of xylem elements and a small nest of phloem elements ${ }^{[4]}$.

Stem: The stem is roughly four angled in sectional view with a wide parenchymatous cortex and four-angled stele. The epidermis is thin and less conspicuous. The outer cortex is made up of four or five layers of radially aligned, small, solid squares parenchyma cells. This zone is uniformly $150 \mu \mathrm{m}$ wide. The inner cortex is much wider, about five rows wide and reticulate layers of narrow parenchyma cells form circular air chambers. The stele has four semicircular thicker bundles located at four corners and two smaller bundles positioned opposite each other. A thin cylinder of small compact, dense xylem elements interlinks the larger and smaller bundles. The vascular bundles are collateral with dense xylem fibers, widely separated radial rows of xylem vessels and a thin arc of phloem. The pith is wide and parenchymatous while the pith cells are circular, less compact and thin walled ${ }^{[5]}$.

Root: The root has an intact, continuous rhizodermis (epidermis) followed by two layers of tangentially oblong compact outer cortex. The inner cortex is wide and parenchymatous. Thin, uniseriate partition filaments, made up of thin-walled parenchyma cells, form wide, radially elongated air chambers. Some of the partition cells have thick walls and are dilated and squarish rectangular. The vascular cylinder has a thin endodermal layer and a pericyclic layer. The xylem consists of five exarch strands and a few wide angular vessels in between the exarch strands. The phloem is in five small groups alternating with the primary xylem strands. The central part is narrow and parenchymatous [6].

Naturally, the herbal drugs contain many chemical compounds. Those compounds which are responsible for therapeutic effect is called as active constituents. There is the number of examples or galenical preparations of the drugs differ to some extent from that of its active constituents of the crude drugs, which can enhance or retard the desired action. The use of isolated active constituents is obvious since these compounds are having a fixed and definite physiological effect. There are so many active constituents still unknown. So the isolating and using the compounds in formulations will potentiate the activity in the modern system of medicine. Column chromatography technique is widely used for the separation, isolation, and purification of chemical constituents from natural drugs [2].

\section{Therapeutic uses in Ayurveda}

- Sweet, sour and bitter in taste, cold in potency; heavy and oily in an attribute.

- Aphrodisiac, tastant, restorative, mucilaginous.

- Useful in inflammation, calculus, hyperactive thirst, diarrhea, poisoning, pain, anemia, abdominal disorders, flatulence, urine retention, burning sensation, rheumatoid arthritis, Prameha, vision disorders, blood disorders.
Seeds are used as Tonic \& for anti-diarrheal and conception promoter Leaf of this plant Used to treat for pain, poison, pretentiousness, abdominal disorders, anemia, constipation, and urinary disorders, and roots have medicinal properties such as coolant, diuretic, aphrodisiac, tonic, and anti-inflammatory and Useful in dropsy, hyper thirst, calculus, strangury, flatulence, and Vata associated disorders [37, 44].

\section{Medicinal Uses}

- Its leaf is useful in a cough.

- It is useful in an anal fistula.

- Its seed is useful in blood disorders.

- Intake of root decoction is useful in jaundice.

- Its vegetable is useful in anemia.

- Topical application of its leaf paste is useful in Prameha.

- Its root is useful in calculus.

- Its root and a whole part decoction are useful in rheumatoid arthritis [45].

- Topical application of leaf paste is useful in lumbago and arthralgia.

- Intake of Talmakhana ash along with cow urine or water is useful in inflammation ${ }^{[46]}$.

- Intake of the decoction prepared from Talmakhana and other medicinal herbs alleviates insomnia ${ }^{[47]}$.

- Intake of root decoction is useful in anasarca.

- Its whole part is useful in dropsy $[37,43,44]$

- Intake powder prepared from Talmakhana fruit powder and sugar along with milk acts as an aphrodisiac [48].

\section{Review Over Pharmacological Activities}

Aphrodisiac activity: The ethanol derived of aerial parts indicates androgenic along with an improvement of sexual behavior in the rat by reliant on dose, improve the histo-architecture of the testis, increase the concentration of sperm count in the epididymis and increase testosterone level. The effect of aerial parts proliferated sexual behavior of male albino rats. The ethanolic extract of Hygrophila auriculata was directed as 100,150 and $200 \mathrm{mg} \mathrm{kg}^{-1}$ doses to rats for a period of 28 days, and the action associated with control rats. The alterations are a weight of organ, sexual behavior, histo-architecture and fructose level of seminal vesicles were observed in a body. The erotic behavior was considered by determining of parameters in aphrodisiac. The ethanolic extract of Hygrophila auriculata showed that evident of anabolic effects in treated animals, by gains weight in the body and reproductive organ. Hygrophila auriculata extracts were showed that ability to raise the development of mature spermatozoa and witnessed in transverse section [19].

Liver protecting activity: The aqueous extract of the whole plant of Hygrophila auriculata has hepatoprotective and antioxidative properties against $\mathrm{CCl} 4$ - and paracetamol-induced hepatotoxicities. Petroleum ether extract of Hygrophila auriculata affects the liver, kidney functions, and metabolism and hematological parameters in high dosage level (40 and $80 \mathrm{mg} / \mathrm{kg})$. Whereas low dose $(20 \mathrm{mg} / \mathrm{kg}$ ) does not exhibit any appreciable toxic action. Methanolic extracts of the aerial parts show hepatoprotective activity against paracetamol and thioacetamide boozing in rats. However, studies show that has against chemically induced hepatic carcinogenesis in Wistar rats. A methanol extract of seed stimulating potential inhibits of hepatic carcinogenesis in Wistar rats. Studied the protective efficacy of acetaminophen-induced liver damage in rats, were studied of hepatoprotective in CC14- induced liver toxicity in rats and antioxidant activity in vitro by using the aqueous extract of roots. shown that has the hepatoprotective activity of a semi-liquid mixture of Hygrophila auriculata against $\mathrm{CCl} 4$ induced liver dysfunction and galactosamineinduced hepatotoxicity in rats $[21,30,31,32,33]$ 
Hypoglycemic activity: Ethanolic extract of aerial parts of Hygrophila auriculata shows signs of reduction in glucose in the blood. Also, the decrease in thiobarbituric acid reactive substances (TBARS) and hydroperoxide in both liver and kidney. This extracts also showed decreased lipid peroxidation allied with increased activity of superoxide dismutase (SOD) and catalase. Reported an effect of hot water extracts of Hygrophila auriculata on glucose tolerance of normal human subjects and maturity onset of diabetic patients. A direction of aqueous extract of Hygrophila auriculata to rats there is no any effect on the gluconeogenic capacity of the kidney or intestinal glucose absorption ${ }^{[28,29]}$.

Hematopoietic action: Petroleum ether extraction from Hygrophila auriculata increases WBC count significantly. The mixture of Petroleum: ether: chloroform extracts of leaf showed significantly increases erythrocyte count, leukocyte count, and hemoglobin count [26]

Antioxidant activity: The methanolic extraction of leaves promising antioxidant activity due to the presence of phenolic compounds and flavonoid ${ }^{[25]}$.

\section{Neurology $[25$}

a. Neuroprotective: Due to the presence of terpenoid element in Hygrophila auriculata shows improvements in cognitive testing and reductions in brain lipid peroxidation with potency comparable to $500 \mathrm{mg} / \mathrm{Kg}$ Vitamin $\mathrm{E}$ by treated in orally for seven days in rats then subject to transient global cerebral ischemia.

b. Aphrodisiac: An ethanolic extract of the seeds $(100-200 \mathrm{mg} / \mathrm{kg}$ ) administered to rats for the increase in growing frequency $(380-472 \%$ of control) and similar reductions in growing, intromission, and postejaculatory latencies; all doses were none significantly more libido enhancing than the active control of $0.5 \mathrm{mg} / \mathrm{kg}$ testosterone injections.

Cardiovascular Health a blood: The chloroform, ethanolic extract of the leaf able to restore a level of blood cells and bone marrow cells in rats which induced by cyclophosphamide- anemia. However, ethanolic extract not in rats are not feeble and assumed to stimulate erythropoiesis and is encountered with a small (possibly clinically irrelevant) decline relative to untreated control [27].

\section{DISCUSSION AND CONCLUSION}

With the advent of modern scientific methods, many of the medicinally important plants approached under chemical examination, important to the isolation of active principles. In a while, their isolation and characterization, these compounds either in the pure state or in the form of well-characterized extracts turn into part of pharmacology. At present, the study on the medicinal plant is one of the important areas of biomedical research. Largely, the pharmacological activity of a medicinal plant Hygrophila auriculata (K. Schum) possesses various biological activities, ranging from analgesic, antitumor, antioxidant, hepatoprotective, hypoglycemic, haematinic, diuretics, free radical scavenging, anthelmintic, anti-inflammatory, antipyretic, and anabolic. Androgenic properties, antimicrobial, antibiotic, insecticidal and hormonal properties, to highly important pharmacological and pharmaceutical activities.

It is interesting to note that the earlier scientific investigations of this plant, Hygrophila auriculata (K. Schum). Mostly, the pharmacological studies have scientifically proved by in vitro and in vivo methods. Therefore, clinical studies are immediately desirable in a mandate to confirm traditional applications using rational phytotherapy and the qualitative analysis along with the quantitative estimation of these components hence forms the basis of the drug development from natural medicinal sources.

\section{Consent for publication}

We certify this manuscript has not been published elsewhere and is not submitted to another Journal

\section{Conflict of interests}

The author(s) have no conflict of interests to declare.

\section{Acknowledgement}

The authority of Department of Botany, Faculty of Sciences, University of Peradeniya, Sri Lanka is thanked, for providing necessary facilities to write this review article.

\section{REFERENCES}

1. Mukherjee P. Quality control of herbal drugs. First edition Ed. New Delhi: Business Horizon pharma publisher, 2002.

2. Anonymous. Quality standards of Indian Medicinal Plants. Indian council of Medical Research. 2003; 1:212-18.

3. Rastogi. Compendium of Indian Medicinal Plants.

4. Vliethink A. Bioassay method in natural product and drug development Netherland: Kluwere Academic publishers, 2001.

5. India Wo. A Dictionary of Indian Raw Materials and industrial products. New Delhi: NISCOM, CSIR, 2002.

6. Sharma P.C. MBYaTJD. Database on Medicinal Plants Used in Ayurveda. New Delhi: Central Council for Research in Ayurveda and Siddha, 2002.

7. The Ayurveda Pharmacopeia of India. New Delhi: Government of India, Ministry of Health and Family Welfare, Department of Indian System of Medicine \& Homeopathy, 1999.

8. Chopra R.N. SLNaICC. Glossary of Indian Medicinal Plants. New Delhi: CSIR, 1986.

9. Satyavati G.V. MKRaMS. Medicinal Plants of India. ICMR, New Delhi, 1976; 107.

10. Asolkar L.V. KKKaOJC. Glossary of Indian Medicinal Plants with Active Principles. New Delhi: Publication \& Information Directorate, CSIR, 1992; 365.

11. Jayatilak P.G. DSP, Murthy B.D., Seth A.R. Effect of an indigenous drug (Spemann) on accessory reproductive functions of mice. Ind J Expt Biol 1976;14:170-73.

12. Vlietinsk AJLV, Totte J, Lasure A, Vanden BD, Rwangabo PC Mvukiyumwami J. Screening of hundred Rwandese medicinal plants for antimicrobial and antiviral properties. J Ethnopharmacol. 1995; 46:31-47.

13. Vanpuyvelde YBaL. Screening of medicinal plants of Rwanda (Central Africa) for antimicrobial activity. J Ethnopharmacol 1986; 16:1-13.

14. Quality Standards of Indian Medicinal Plants. New Delhi: Indian Council of Medical Research, 2006.

15. Chopra R.N. SLNaICC. Glossary of Indian Medicinal Plants. New Delhi: NISCAIR, CSIR, 2006.

16. Chauhan NS, Sharma V, Dixit VK. Effect of Hygrophila auriculata aeria parts of on the sexual behaviour of male rats. Nat Prod Res. 2011; 25(15):1423-31. Epub $2011 \mathrm{Jul} 8$.

17. Chauhan NS, Sharma V, Dixit VK. Effect of Hygrophila auriculata aerial parts of on the sexual behaviour of male rats. Nat Prod Res, 2011.

18. Doss A. Preliminary phytochemical screening of some Indian Medicinal Plants. Anc Sci Life, 2009.

19. Hygrophila auriculata (L.) Nees, Acanthaceae: chemistry, traditional, medicinal uses and its pharmacological activities - a review.

20. Jayesingha WA, On Hygrophila Spinosa (Vel Asteracantha Longifolia). $\mathrm{Br}$ Med J. 1887.

21. Ahmed S, et al. Anti-tumor promoting activity of Hygrophila auriculata against experimental hepatocarcinogenesis in rats. Food Chem Toxicol, 2001.

22. A Comparative Evaluation of Phytochemical Fingerprints of Hygrophila auriculata Nees. Using HPTLC.

23. Misra TN, et al. Constituents of Hygrophila auriculata. Fitoterapia, 2001.

24. Thankamma A, Rheumatoid arthritis and astercantha longifolia. Anc Sci Life, 1999.

25. Kanhere $\mathrm{R}$, et al. Neuroprotective and antioxidant potential of terpenoid fraction from Hygrophila auriculata against transient global cerebral ischemia in rats. Pharm Biol, 2013.

26. Haematopoietic activity of Hygrophila auriculata on cyclophosphamideinduced bone marrow suppression. 
27. Pawar RS, et al. Erythropoietic activity of Hygrophila auriculata (Nees.) in rats. J Ethnopharmacol, 2010.

28. Vijayakumar $\mathrm{M}$, et al. Action of Hygrophila auriculata against streptozotocin-induced oxidative stress. J Ethnopharmacol, 2006.

29. Effect of Artocarpus heterophyllus and Asteracanthus longifolia on glucose tolerance in normal human subjects and in maturity-onset diabetic patients.

30. Shanmugasundaram $P$, Venkataraman S. Hepatoprotective and antioxidant effects of Hygrophila auriculata (K. Schum) Heine Acanthaceae root extract. J Ethnopharmacol, 2006.

31. Raj VP, et al. In vitro and in vivo hepatoprotective effects of the tota alkaloid fraction of Hygrophila auriculata leaves. Indian J Pharmacol, 2010.

32. Singh A, Handa SS. Hepatoprotective activity of Apium graveolens and Hygrophila auriculata against paracetamol and thioacetamide intoxication in rats. J Ethnopharmacol, 1995.

33. Shivashangari KS, Ravikumar V, Devaki T. Evaluation of the protective efficacy of Hygrophila auriculata on acetaminophen-induced liver damage in rats. J Med Food, 2004.

34. Hewawasam RP, et al. Protective effect of Hygrophila auriculata extract in mouse liver injury induced by carbon tetrachloride and paracetamol. J Pharm Pharmacol, 2003.

35. Kirtikar KR, Basu BD. Indian medicinal plants (Vol. 1-4). Dehradun, India: International Book Distributors Booksellers \& Publishers, 1999

36. http://www.itis.gov/servlet/SingleRpt/SingleRpt?search_topic=TSN\&searc h_value $=182343$.

37. Sheth AK. The herbs of Ayurveda (Vol. 1-4). Gujarat, India: Shet Publishers, 2005.

38. Chunekar KC, Pandey GS. Bhavaprakasa Nighantu. Varanasi (India): Chaukhambha Bharati Academy Publishers \& Distributors, 2010.

39. Vaiya Saligram. Saligrama-Nighantubhusnam. Mumbai (India): Khemraj Shrikrishnadass Prakashan, 2007.

40. Tripathi Indradev. Rajanighantu. Fifth Edition. Varanasi (India) Chaukhambha Krishnadas Academy, 2010.

41. Sharma Priya Vrat, Sharma Guru Prasad. Kaiyadeva-Nighantu. Second Edition. Varanasi (India): Chaukhambha Orientalia, 2006.

42. Sharma PV. Dravyaguna-Vijyana. Vol.II. Varanasi (India): Chaukhambha Bharati Academy Publishers \& Distributors, 2011.

43. Pullaiah T. Encyclopaedia of world medicinal plants (Vol. 1-4). New Delhi, India: Regency Publication, 2006.

44. Rao B. Rama. Astanghrdayam. First Edition. Varanasi (India): Chaukhambha Visvabharati Oriental Publishers \& Distributors, 2009.

45. Gaur Banwari Lal. Astanghrdayam. First Edition. Varanasi (India): Chaukhambha Orientalia, 2007.

46. Tripathi Brahmanand. Astanghrdayam. Second Edition. Delhi (India): Chaukhambha Sanskrit Pratishthan, 2009.

47. Sharma Priya Vrat. Cakradatta. Fifth Edition. Varanasi (India): Chaukhambha Publishers, 2007.

48. Tripathi Harihar Prasad. Harita Samhita. First Edition. Varanasi (India): Chaukhambha Krishnadas Academy, 2005.

49. Sharma Anant Ram. Susruta SaÅhita Vols.I-III. First Edition. Varanasi (India): Chaukhambha Surbharati Prakashan, 2001.

\section{HOW TO CITE THIS ARTICLE}

Sarvananda L., Amal D. Premarathna. Ethnopharmacolological potential and medicinal uses of Hygrophila auriculata. J Ayu Herb Med 2018;4(4):185-188. 